To be cited as follows:

Barbato, G., Fumasoli, T. and Turri, M. (forthcoming) The role of the organisational dimension in university positioning: a case-study approach, Studies in Higher Education (online November 2019)

\title{
The role of the organisational dimension in university positioning: a case-study approach
}

\begin{abstract}
This paper argues that university strategic positioning is influenced by the organisational dimension, operationalised along the variables of organisational structure, identity and centrality. A comparative case study is presented including two English and two Italian universities and drawing on a set of sixty interviews with academic leaders, managers and administrators. The analysis of the trajectory of the four universities from 2004 to 2018 illustrates the articulation of the link between organisation and position and makes sense of the distinctive balances between environmental pressures and strategic agency in university strategic behaviour. Finally the paper outlines six propositions on the expected impact of the organisational structure, identity and centrality on positioning processes of universities.
\end{abstract}

Keywords. organisational dimension, structure, identity, centrality, positioning

\section{Introduction}

The debate on both organisational behaviour and university agency has been largely influenced by an environmental determinism perspective according to which organisational actorhood is the result of compliance with isomorphic exogenous pressures in order to gain legitimacy (Astley and Van de Ven 1983; Fumasoli and Huisman 2013). Based on this approach, organisational research 'has moved its focus, empirically and theoretically, from the organisation to the field, population, and community' (Greenwood and Miller 2010, 80) in order to analyse if and how organisations respond similarly to external macro-level forces and which model they tend to imitate. Consequently, a meso organisational level of analysis has been increasingly neglected (Clark 1983; Greenwood et al. 2011). In response to this situation, several scholars have urged the reappraisal of the organisational dimension as a valuable level of analysis. Greenwood et al. (2014, 1206-1207) argue for 'the need to rethink this shift in the balance of emphasis, to re-emphasise an organisational level of analysis, and to treat organisations as actors'. Similar claims can be found in the Higher Education (HE) literature. Fumasoli and Stensaker (2013) underline that greater attention should be paid to organisational processes as a valuable analytical perspective that can help understand those factors that support 
university survival against increasingly complex challenges. Similarly, Paradeise and Thoenig (2013, 196) use the concept of 'local order' to argue that universities should be treated as a meso-level order and action level to 'break free from the all-pervasive global or one-size-fits-all standard'. Likewise, studies adopting a managerial rationality approach (Astley and Van de Ven 1983) also recognise that strategic change cannot be described as the mere result of the leadership's intent and action since other organisational-level elements prove to be crucial (Toma 2010; Stensaker et al. 2014).

This paper sets out to contribute to this debate by analysing how the organisational dimension influences strategic positioning processes of universities, in order to formulate a set of expectations on this relationship. Positioning is indeed an increasingly significant topic for both researchers and policy makers. The ongoing massification and globalisation of HE, the growing competition and increasingly diversified demands from the so-called knowledge economy and society, encourage universities to consider carefully on which activities and resources they should focus, i.e. to position themselves distinctively (Fumasoli and Huisman 2013). Moreover, studies on university positioning have concentrated more on measuring the distinctiveness of these institutional efforts and on analysing the balance between distinctiveness and compliance (Morphew et al 2018; Seeber et al. 2019). Less attention has been paid to the role of the organisational dimension in influencing the effectiveness of these processes. In particular, studies have mainly concentrated on just one organisational variable, such as the organisational identity (Fumasoli et al. 2015; Stensaker 2015) or the governance style (Stensaker and Vabø 2013; Pinheiro and Stensaker 2014), whereas fewer works have adopted a more holistic approach (Fumasoli and Lepori 2011; Paradeise and Thoenig 2016; Vuori 2016). This paper aims to fill this gap through a multiple case-study analysis based on a comprehensive conceptualisation of the organisational dimension. For this reason, a framework of analysis is outlined in the next section.

\section{A framework for analysis}

The organisational dimension is a broad and general concept that needs to be operationalised in order investigate its influence on positioning processes. Our operationalisation relies on previous studies that have identified different sets of variables that are relevant to our study (Greenwood et al. 2011; Fumasoli 2015; Seeber et al. 2015; Paradeise and Thoenig 2016).

Greenwood et al. (2011) identify four main organisational attributes, namely the organisation's position within a field, its structure, ownership and governance, and identity, which are claimed to 'frame how organisations experience institutional complexity and how they perceive and construct the repertoire of responses available to them'. Fumasoli (2015) illustrates an organisational approach to examine organisational actorhood within multi-level governance in higher education, and outlines three variables - structure, membership and identity, organisational centrality - to capture universities' strategic behaviour and positioning patterns. Seeber et al. (2015) drawing from the framework presented in Brunsson and Sahlin-Andersson (2000), use the three main dimensions of identity, hierarchy and rationality to study changing organisational forms in higher education. Finally, Paradeise and Thoenig (2016) discuss how organisational processes, specifically human resources management, governance style and the creation of a shared institutional identity, are decisive for building strategic capacity of universities.

While all these studies advocate a meso level of analysis and operationalise the organisational dimension in order to explain organisational behaviour, their theoretical underpinnings are different. For Greenwood et al (2011) the organisational dimension is a filter of macro level institutional logics that are accommodated in organisational structures and processes. In other words, the institutionalist approach according to which global scripts shape the social world is maintained. Seeber et al 2015 
also characterise external forces, in this case policy reforms, as major drivers of organisational change, offering a fine-grained analysis of policy implementation by looking at the extent to which universities have been transformed according to political agendas.

Fumasoli 2015 and Paradeise and Thoenig 2016 provide on the other hand a more nuanced perspective, by highlighting the organisational dimension as a key determinant of universities' strategic capabilities. In this sense, their works conceptualise universities as organisations equipped with agency on their own and thus able not only to respond to but also to shape their environments.

Reflecting the distinctive approaches on environmental forces and university strategic agency, we have elaborated three variables: organisational structure, identity, and centrality. These variables represent a systematic attempt to operationalise the organisational dimension by taking into consideration the main strands of the literature as discussed above ${ }^{1}$. These three variables are now described and a summary of them is illustrated in Table 1.

Table 1. Variables, analytical dimensions, and indicators of the organisational dimension

I. Organisational structure The organisational structure 'reflects how hierarchy and authority are designed and dispersed' within the organisation (Fumasoli 2015, 90). First of all, the structure can be empirically investigated by analysing the governance of the organisation. The term governance refers to the way universities are governed, in other words, the set of structures, procedures, and actors through which decision-making is organised within them (Kezar 2004; Frølich and Caspersen 2015), and it can be investigated through its degree of centralisation (1a) and formalisation (1b) (Seeber et al. 2015; Maassen et al. 2017).

Centralisation (1a) refers to the locus of the decision-making and underlines the complex relationship between the choices of the institutional leadership and the degree of autonomy of the peripheral structures (faculties/departments) in implementing those choices (Maassen et al. 2017). Centralisation also refers to the managerial orientation of decision-making and, therefore, to the distribution of competences between the board of governors, the institutional leadership (the senior management team) and the collegial bodies (senate/academic board). Other relevant factors that impact on the degree of centralisation of the governance are the type of task allocation (e.g. matrix vs. divisional structure) (Pinheiro and Stensaker 2014), the size and composition criteria of the senior management team (Taylor and Machado 2006). Formalisation (1b) concerns how decision-making is managed. This can be left to spontaneous actions and ideas of the internal actors or based on more rational processes that rely on management-by-objectives, evaluation and monitoring mechanisms (Seeber et al. 2015). Centralisation and formalisation have acquired increasing importance within universities as a result of reforms placing great emphasis on internal hierarchies and accountability, even if these are in contrast with traditional academic values, such as the autonomy of academics and selfgovernance of the university (Frølich and Caspersen 2015). Higher centralisation and formalisation may be expected to support strategic positioning through the creation of a more integrated and effective governance (Pinheiro and Young 2017). Yet, other studies have underlined that participation and consultation are equally important since they create trust among university members, thus legitimising top-down decisions more legitimated (Kezar 2004; Stensaker and Vabø 2013).

A third factor that certainly influences the complexity of the structure is the size of the organisation (1c). In the case of universities, size can be investigated by considering either the number of students and academic staff or the number of departments/faculties. This latter is particularly important since 
it determines how many internal stakeholders the institutional leadership of the university has to deal with.

II. Organisational identity It has been widely argued in the HE literature that each university is characterised by a cultural dimension in addition to its organisational structure (Clark 1983); a set of beliefs and values shared by the internal members of the organisation that distinguish it from the others (Czarniawska 1997; Stensaker 2015). Identity can be studied along a continuum between integration and fragmentation, as suggested by Fumasoli (2015). Scholars recognise different sources of both integration and fragmentation of the identity of a university (Clark 1983). First, disciplines constitute a factor of fragmentation since academics favour their belonging to a disciplinary community and their compliance to the related categories of thought and code of conduct (Weick 1976). By contrast, the identification of internal members with their academic institutions constitutes a bonding element that contributes to generating a strong overall sense of collective effort and, as a result, a university culture (Clark 1983). An integrated identity is generated primarily by a strong identification with enduring features (e.g. traditional mission, history) that uniquely distinguish the university. Yet, it is also claimed that identity is dynamic in the sense that it evolves according to both the institutional leadership's strategic aspirations (what the university wants to become) and the challenges of the external environment (Stensaker 2015). Consequently, the management of the identity from the top management is a relevant process in order to maintain organisational integrity (Morphew et al. 2018). On this view, factors such as the socialisation of newcomers, the criteria for career progression (Paradeise and Thoenig 2016), the flow of internal communication and sensemaking processes can contribute to enhancing the integration universities' identity (Gioia and Thomas 1996). Sense-making, for example, sustains strategic change since it contributes to making complex circumstances more comprehensible and manageable for university staff (Vuori 2015). Hence, the organisational identity presents both dynamic and enduring components that seem equally important for generating an integrated university identity (Fumasoli et al. 2015).

\section{Organisational centrality}

We conceptualise organisational centrality as a multidimensional variable that expresses how exogenous features, affect positioning processes of universities. Some studies that adopt an organisational approach already propose similar conceptualisations. Greenwood et al. (2011) argue how an organisation's position within an organisational field constitutes a filter in confronting environmental pressures. This can be done differently depending on whether a university is at the centre or at the periphery of the field, in the latter case a university would be less embedded in institutionalised relationships and related expectations. Fumasoli (2015) adopts the concept of organisation centrality claiming that every university is located on a continuum between centre and periphery that can be understood in several ways (geographically, politically, economically, culturally). This implies that a location closer to the centre 'constitutes an important factor affecting its possibilities to gather material and symbolic resources' (Fumasoli 2015, 92). This assumption could be useful to understand processes of strategic positioning as well, as universities would tend to position themselves in those niches that provide them with the necessary resources.

In this paper, centrality is to be intended in economic (3a) and social (3b) terms. In economic terms (3a), a central location means that a university is located in an industrialised and economically developed area, city or district. In such contexts, universities can hypothetically attract additional 
resources from activities such as knowledge transfer, collaboration with businesses, which could be extremely important especially in those HE systems where competition for students is high and government funding is decreasing. By contrast, a peripheral location in economic terms is represented by operating, for instance, in a rural area, an economically depressed area, a post-industrial area, a scarcely populated area, a climate-wise difficult area, that offer thus fewer opportunities to universities.

A central location in social terms (3b) means that a university carries out its activities geographically close to several other universities that compete for the same resources (e.g. students, funds from industry). Therefore, being central in social terms implies higher levels of competition and consequently more difficulties to obtain critical resources. Universities could either imitate the most successful competitors or strive for differentiation in specific dimensions in order to avoid competition (Seeber et al. 2019) or even moderate competition through cooperative networks.

As illustrated in Table 2, the economic centrality of universities is here empirically expressed by looking at information such as the number of active firms or the Gross domestic product (GDP) of region $^{2}$ of the university. Social centrality is expressed by the number of universities within a $50 \mathrm{~km}$ radius, as suggested by other studies (Cattaneo et al. 2018; Seeber et al. 2019).

\section{Methodology and data}

This paper adopts a qualitative case-study approach. This methodology is particularly suitable to answer exploratory research questions that are characterized by the absence of previously defined expectations on the relationship between variables object of study (Byrne and Ragin 2009). In the present paper, the case-study methodology is purposively adopted to identify some expectations/propositions on the relationship between the organizational variables described in section 2 and positioning processes of universities.

Hence, four universities have been selected as case studies. Two universities belong to the Italian HE system (University A and B), whereas the other two (University C and D) belong to the English system. These two countries present certainly some differences. The English system has seen increasing internal competition for resources among HEIs in recent decades especially due to the introduction of variable tuition fees for students (since 2006) and their increasing cap over the years, as well as other market-based reforms (Brown and Carasso 2013). Likewise, an increasing portion of public funding has been linked to the national assessment of research ${ }^{3}$ that, since 1986, has evaluated the quality of research publications by UK universities. Moreover, English universities have seen the introduction of the so-called "managerialism" and related reforms since the 1980s, with the Jarratt Report in 1985 (Shattock 2017). More defined internal hierarchical structures together with a high institutional autonomy potentially give English universities a significant role in strategic actions.

By contrast, competition for students and funds has been traditionally weak among Italian universities even if it has recently increased (Capano et al. 2016). This is claimed to be the result of both decreasing funds from the government and increasing public funds based on performance-based criteria linked to the research assessment exercise (VQR). Moreover, the NPM-inspired reform in 2010 (law no. 240) significantly changed the governance of Italian universities, strengthening the role of the rector and that of the board of governors, and reducing that of the Senate, which has traditionally expressed the self-governance of academic guilds (Capano et al. 2016). The reform also merged teaching and research functions under the authority of departments, decreasing substantively the role of faculties. The 2010 reform along with growing competition started, at least theoretically, 
to develop a more strategic behaviour in Italian universities, even though their institutional autonomy is limited compared with the autonomy of British institutions (Seeber et al. 2015).

Despite these differences, England and Italy are quite similar in terms of number of universities and students in the HE sector. Other similarities are the presence of a historical evaluation exercise of research connected with a performance-based funding and a comprehensive quality assurance system. In order to increase the comparability between the Italian and the British case-studies, we decided to select, by using a purposive sampling, universities that share several characteristics, illustrated in Table 2. All these universities are small or medium in terms of size and cannot be considered worldclass universities. The case-studies differ instead in terms of economic and social centrality to verify how different values of these variables impact on positioning processes.

Table 2 Main features of the case-studies

For each of the four case-studies, data has been gathered from multiple sources, including 60 semistructured interviews with different type of actors (rector/vice-chancellor; pro-rector/pro-vicechancellor; senior and middle administrative staff; head/dean of department/faculty; academics with managerial responsibility) in each university and the analysis of documents such as strategic plans, charters, and statutes. This has enabled us to triangulate the data and increase their significance. Interviews were performed face-to-face and audio recorded, while anonymity of the interviewees and the correspondent university has been ensured. Interviews lasted an average of 45 minutes. The sample of the 60 interviewees (Table 3) was heterogeneous in terms of roles, disciplinary affiliation and gender (32 men and 28 women).

Since this study considers a period of 15 years (from 2004 to 2018), the sample of the interviewees was constructed accordingly. Each university presents one or more periods that correspond to the period of office of the rectors/vice-chancellors in those universities ${ }^{4}$. Each new rector/vice-chancellor usually changes part of the (if not the entire) senior management team and thus represents an element of organisational change. Even if each interviewee was asked questions about the period in which they had specific posts, some interviewees had held their posts for more than a single period, providing a useful diachronic perspective.

The collection of the data followed a two-step process. First, to acquire in-depth knowledge of the key events that occurred between 2004 and 2018 in each university, an exploratory interview was conducted with a key figure in the governance of the university over a long period of time. Besides reconstructing the recent history of the university and gathering documentary sources, this first interview also helped to identify key respondents in the second step. All interviews were transcribed by using an analysis grid based on the three organisational variables. Each question of the interview reflected our operationalisation of the organisational dimension (Tab. 1). This process of data organisation allowed us to identify systematically the relevant information and common trends among the case-studies, which was useful for structuring the next section.

Table 3. Interviewees per case-study and period of office of the rector/vice-chancellor

\section{Results and discussion}

In this section, we examine, across the four case-studies the three variables used to operationalise the organisational dimension (structure, identity and centrality) in order to illustrate their relationship to the positioning processes of the four universities. The symbol \# refers to the interviewees indicated in Table 3. 


\section{Organisational structure}

The relationship between this variable and positioning processes is viewed through the three dimensions highlighted in Tab. 1.

\section{Centralisation}

First, all of the case-studies underline, even if to different extents, an increasing process of centralisation (1a). On the one hand, senior management team' responsibilities have been better defined and expressed in small and cohesive groups that very often include the senior administrative staff, and with academic members chosen for their managerial competencies rather than to represent their disciplinary community (\#1,\#3,\#23,\#36,\#48,\#53). Concurrently, task allocation increasingly takes on a 'matrix' structure (Univ. A, B, D) where the senior management team collaborates directly with the administrative staff of each faculty/department in several areas (\#2,\#52,\#59). For example, Universities A and B have established permanent thematic working groups (e.g. on internal research assessment procedures or the establishment of spin-offs and patents) composed of representatives of every department and a member of the senior management team. Moreover, University D's middle administrative staff of the faculties report directly to the corresponding pro-vice-chancellor instead of the dean. On the other hand, the locus of decision-making has been increasingly concentrated in the relationship between the senior management team and the board of governors, with a decreased influence from the Senate (Univ. A, B, D). In Italian universities, this is clearly the result of the abovementioned reform (law no. 240/2010). Small and "managerial" teams together with the shift in the locus of decision-making have produced clearer and faster decisions, as declared by several interviewees (\#13,\#25,\#55). By contrast, when the senior management team is larger and more disciplinary-based and 'collegial' bodies exert a stronger influence, the perception is that decisionmaking is slower and under constant negotiation (Univ. A, period 2; Univ. B, period 1) (\#11,\#17,\#20,\#21). Similarly, a strong complementarity of the senior administrative staff within the senior management team, as well as a 'matrix' structure, have increased coordination between the institutional core and the peripheral structures of the university, reducing risks of internal heterogeneity (Taylor and Machado 2006; Pinheiro and Stensaker 2014) (\#1,\#2,\#24,\#52,\#60). Therefore, this hierarchisation has produced an increasing institutional coherence over time (Toma 2010; Fumasoli and Lepori 2011); in other words, it contributes to creating a more integrated rather than loosely coupled organisation, which has a positive impact on the university's capacity to pursue a positioning choice (Paradeise and Thoenig 2016). As claimed by Pinheiro and Young (2017, 130), a 'tighter coupling [...] provides both the capabilities and the legitimacy necessary to enforce change on the institution as a whole, allowing it to act as a single unit pursuing collective aims'.

However, these case-studies have also shown that institutional coherence cannot be achieved solely through hierarchisation. Centralisation has in fact grown concurrently with formal and informal practices that allow faculties/departments to be involved, to some extent, in the decision-making process. Formal mechanisms, such as the presence of the deans of the faculties in the senior management team (Univ. C, D) or other advisory bodies (Univ. A, B), have made possible the inclusion of the specificities of each faculty, with the deans as a buffer between the core and the peripheral structures (Frølich and Caspersen 2015). Similarly, in all case-studies routines emerge as equally important in enhancing internal participation. Examples are the weekly/monthly meetings of the heads/deans of departments/faculties before the assemblies of the senate as well as open meetings in the faculties whose main aim is to broaden the debate, allowing people to feel that they can contribute to the evolution of the university (\#15,\#32,\#36,\#40,\#45,\#58,\#59) These practices have 
created trust and engagement of individuals which legitimate the entire positioning effort (\#6,\#7,\#33,\#41), confirming the findings of previous studies (Kezar 2004; Fumasoli and Lepori 2011; Stensaker and Vabø 2013; Stensaker et al. 2014). Conversely, imbalanced centralisation erodes the internal consensus and trust, generating discontinuity in the implementation of positioning since the new subsequent rector/vice-chancellor usually aimed to be perceived as different from the previous (Univ. A and D, the transition from period 1 to 2) (\#8,\#10,\#53,\#60).

\section{Formalisation}

Second, centralisation has been often matched by a growth in the formalisation (1b) of decisionmaking that is increasingly data-driven and subject to ongoing planning and assessment mechanisms. All the case-studies show the growing relevance and spread of strategic planning processes and the increasing centrality of evaluation mechanisms (\#2,\#12,\#35,\#54). Formalisation gives positioning a more structured nature since the strategic plan is used as a management tool, which is further implemented through indicators/targets that are employed as benchmarks to assess if the organisation is going in the expected direction (\#4,\#34,\#42,\#55). The strategy of University D for the second period was developed through the guidance of a consulting company that organised roundtables for the external stakeholders (students; businesses; region and society) and the representatives of the institutional leadership, whereas the previous strategy had been merely developed and managed within and the latter. From this process several implementation plans were developed, as also emerged in other universities (Univ. A, B, C). Moreover, evaluation systems can be used to align the goals of the faculties/departments with the objectives of the institutional leadership, through a system of interconnected strategic planning (Univ. B, D). Finally, when decision-making is data-driven, based on processes of monitoring and evaluation, organisational changes are perceived as less personalistic and more objective, enhancing their internal acceptance (\#3,\#14,\#43,\#52).

However, it should also be stressed that increasing formalisation generates fruitful effects only if it is not perceived as a mere instrument of control. For example, the two heads of departments of University B, declared that, although the elaboration of the departments' strategic plans had to referred to the university' strategic plan, each department had the possibility to adapt each strategic goal according to its peculiarities. In addition, this process was carried out by several informal meetings between the Senior administrative officer for strategic planning and the management team of departments, which were claimed to generate engagement and clarity for both (\#32,\#33,\#35). By contrast, if evaluation is perceived as a mere control, this leads to resistance from faculties' members that can either hamper these processes or implement them only ceremonially (Univ. A, period 3; Univ. D, period 1) (\#14,\#15,\#51).

Size

Third, in relation to the size of university (1c), a smaller size proved to be crucial in supporting the balance between centralisation and involvement of faculties/departments (\#35,\#39,\#47), leading also to a more shared and integrated decision-making process. A smaller size allowed all the deans of faculties/departments to be part of either the senior management team (Univ. C, D) or members of the senate (Univ. A, B). Moreover, at University C, which consists of only three faculties, centralisation processes were less evident while the involvement and participation of peripheral structures in decision-making processes was more easily managed (\#36,\#37,\#41,\#45). This seems to support Birnbaum's argument (1991) that centralised organisational structures are more important in larger institutions. 
However, a smaller size obviously implies also that a university may have more difficulties in acquiring external resources especially if these are competitive as research funds. The senior administrative officers of Universities $C$ and $D$ argued that the scale of their research did not allow to compete successfully with older and larger universities in the national exercises of research evaluation (\#42,\#54). This clearly influenced the distinctiveness of their positioning by either pushing their research towards a more applied and industry-linked research in order to attract additional revenues $(\# 48, \# 57)$ or by focusing on attracting students through new campuses, facilities and placement services (\#43).

\section{Organisational identity}

All case-studies highlight that when the identity of a university is more integrated (2), this has a positive impact on positioning processes. An integrated identity provides indeed moral incentives and individual engagement towards the intended strategic change (Clark 1998; Stensaker et al. 2014; Paradeise and Thoenig 2016). Interviews showed that this integration is generated by both enduring and dynamic aspects of university identity. First, enduring features (Czarniawska 1997), such as the history of the university, its traditional mission, and the connection with its local area prove to be elements that are generally shared also among different disciplinary communities and that contribute to strengthen individuals' sense of belonging to their university (\#1,\#16,\#22,\#26,\#44,\#58), confirming B. Clark's (1983) argument on centrifugal and centripetal dynamics in higher education. Moreover, a more specialised subject mix seems to reduce the risk of a fragmented identity (Universities B, C). Furthermore, the disciplinary communities that founded the university proved to be those in which the sense of a shared identity was stronger, thus confirming hypotheses from old institutionalism scholars (Stinchcombe 1965). Instruments such as entry requirements and criteria for career progression were deliberately used to promote these values with newcomers (Paradeise and Thoenig 2016). For example, showing the impact of academic research to society and economy is one of the main criteria for career progression at University D, since it expressed its historical mission as college of advanced technology (\#52,\#57). Moreover, cultural and social events (Univ. A, B, C) prove to be valuable means to reappraise the specificities of a university and constitute an element of integration of the identity. All the events for the celebration of the $150^{\text {th }}$ anniversary of University B's foundation, for instance, were designed to spread a shared sense of honour of being part of this centuries-old institution (\#27,\#31).

Second, interviews underline that each institutional leadership proposes its own strategic vision about what the university intended to become, in other words, how the identity of the university could evolve in a changing environment without losing its traditional values. Confirming Gioia and Thomas (1996) and Stensaker (2015), besides the shared recognition of historical traits, the university identity presents a dynamic aspect that results from an internal and socially-constructed process. Therefore, an integrated identity is also the result of a strong sense of identification of internal members in the strategic vision proposed by the institutional leadership. All the case studies equally illustrate how the this undertook formal and informal processes aimed at increasing the sense of membership of academics and of the administrative staff to the university (\#3,\#5,\#28,\#33,\#42,\#46,\#55,\#58). Sensemaking processes proved to be crucial in this regard, indeed changes that could potentially disrupt the ordinary operation and create uncertainty were introduced through a systematic interaction between the main internal actors. This interactive process not only help communicate where and how the university wants to position itself (Vuori 2015) but also determines how each part of the organisation could contribute to it (\#7,\#32,\#36,\#52). Common examples that have been found in all 
the case studies are regular public meetings between the senior management team and members of departments/faculties, and ongoing internal communication from the vice-chancellor/rector's to the administrative and academic staff. Several interviewees from University A point out, for example, that continuing training, team building activities and weekly meetings with the general administrative director significantly contributed to empowering the entire middle administrative team (\#2,\#4). Feeling part of a large and comprehensive project becomes ultimately a kind of moral incentive which generates engagement in the proposed organisational change and thus impacts positively on positioning (Stensaker 2015).

When these processes are not thoroughly managed, the risk for fragmentation of the identity seems to be higher, and engagement concentrates only within those academic and disciplinary communities that are more involved in the senior management team. This creates a disciplinary-based fragmentation that impacts negatively on the implementation of the overall positioning process (\#14,\#15,\#50).

\section{Organisational centrality.}

\section{Economic centrality}

A central location in economic terms (3a) has a positive impact on positioning since universities have greater opportunities to access a range of diversified additional resources which financially support strategic organisational efforts. Establishing formal relationships with the local economy not only enhances the link between graduates and the labour market (e.g. through the involvement of companies in curriculum development) but also provides funds for joint research (\#52,\#54). Moreover, if a territory offers indeed several types of business activities in different sectors, a university can decide in which niche concentrate its relationships based on its strengths and the level of competition of the niche. University D's relations with local industry have focused on small and medium-sized enterprises to avoid competition with the old, high-status and research-oriented university located in the same city, which holds stable relationships with multinational corporations (\#49,\#60). Similarly, also University B enjoys the opportunities offered by its diversified and developed economic environment. On the one hand, University B collaborates actively with the large enterprises in the chemical sector. On the other hand, University B deliberately used its location in one of the most important cultural centres of Italy, to attract international students and researchers (\#24,\#30).

However, even if a peripheral position naturally provides fewer opportunities supporting positioning, this assumption cannot be taken for granted. Indeed, University A shows how this negative condition can be partially reversed over time if universities act as "agents of local development" (Rossi and Goglio 2018), in other words, by becoming themselves a new centre of development for the surrounding environment. University A has become an important centre for the creation of spin-offs, patents and start-ups, by fostering entrepreneurial opportunities within the region. To strengthen the relationship between the university and the local economic fabric, the main local stakeholders are involved directly in the life of the university, through a specific statutory body, which contributes in the definition of the institutional strategic direction. These attempts have created positive externalities and contributed to creating a distinctive image of the university as a centre of innovation, thus (in the long-term) also activating financial resources (\#6,\#16,\#47). However, as emerged from Universities A, this type of proactive behaviour is not an intrinsic consequence of the peripheral location, but always a deliberate choice of the institutional leadership supported by an effective and cohesive organisational structure (\#1,\#2,\#36). 


\section{Social centrality}

Second, centrality in social terms (3b), expressed by a higher geographical proximity to other higher education providers, undeniably increases competition for funds. This has been particularly recognised from interviewees of University $\mathrm{D}$, which is located in a metropolitan county with other 7 universities; and by University C, which compete with other 10 universities within a $50 \mathrm{~km}$ radius. The higher the proximity to other institutions the more universities aim to be distinctive, especially with respect to competition for students. So, for example, University D has attracted a significant share of its students from disadvantaged backgrounds and lower social classes because it is acknowledged to be a very good social elevator through its training and student placement services (\#52). University D distinctiveness stems instead from becoming a centre of excellence in a small number of disciplinary areas (e.g. nursery and teaching training), so much so that it attracts students from the entire country (\#47).

However, the case studies also show that the closeness to other universities could support the launch of a network of universities whose aim is to coordinate themselves, reducing competition and creating economies of scale, as shown also in Vuori (2016). Interviewees from University D, for example, underline that being part of regional networks of universities allows them to participate in the competition for research funds that required explicit collaboration between institutions. Cooperative networks have also been developed with an international scope. All the four universities have invested heavily in the establishment of formal collaborations with other universities abroad to be perceived as an 'international university' (\#38,\#56). For example, $24 \%$ of the students of University D come from outside the UK in 2017, while University B developed more than 25 double and joint degrees with other universities all over the world since 2004. Finally, being in a peripheral position in social terms does not seem to affect negatively the effectiveness of positioning processes, rather, it defines the available options for universities to find their own niche.

\section{Concluding remarks}

By considering the organisational dimension as a fruitful level of analysis, this paper has examined how its influence on institutional positioning efforts. The analysis of the case-studies allows to formulate six propositions that express the expected impact of the organisational structure, identity and centrality on positioning processes of universities. These are summarised in Table 4.

Table 4 Propositions and intervening factors on the impact of each organizational variable on positioning processes

Concurrently, the case studies also show how this relationship cannot be conceived as deterministic since two factors make it much more complex and unpredictable.

First, it is possible to identify some intervening factors (Table 4) that, at least partially, modify the expected relationship between the three organisational variables and positioning processes. If we consider the organisational structure, for example, the positive effects of centralisation on positioning have somehow to be balanced with the involvement of faculties/departments' members to have an integrated approach throughout the organisation. Similarly, while a higher geographical proximity to other universities (social centrality) certainly entails more competition for resources, it could also provide opportunities to create collaborative networks among universities. 
Second, the connection among the three variables can affect the expected relationship between each of them and positioning processes. While this requires further investigation, some examples have emerged from our case studies. The behaviour of an "agent of local development", especially apparent in the case of University A, is clearly the result of a centralised governance supporting outward actions through specific goals in the strategic plans, successively implemented through the creation of specific administrative offices and even a statutory body. Likewise, the limited size of University $\mathrm{C}$ (only 3 faculties) and the long mandate of the vice-chancellor supported the creation of a strong and shared sense of identification with the strategic direction of the university. This has made it possible to maintain a less centralised governance without losing institutional coherence and administrative capacity. Finally, all the case-studies highlight that an integrated identity provides moral incentives for internal members even when decision-making is more top-down.

The analysis conducted in this paper entails a simple but not simplistic policy indication. In the rush to adopt quick-fix solutions, there might be the risk of focusing only on strengthening internal organisational structures and procedures. However, this paper has shown that informal practices, routines, ofsense-making processes are relevant factors that support strategic efforts like positioning. These informal systems of decision making cannot be introduced merely by law and are more the result of socially-constructed and long-term dynamics that underline the importance of human relationships within organisations (Kezar 2004). Since university positioning is becoming an increasingly central concern for national and local policies, this article is also an invitation for policymakers to reflect on the role that the organisational dimension can exert on such processes.

Finally, this study has two main limitations which also suggest directions for future research. First, the selection of four case-studies did not allow to capture the variety of universities that could be found in a HE system. In particular, it could be important to expand the sample by investigating the same three organisational variables in a large, old and top-research university where collegial mechanisms of governance might still be decisive, such as Oxbridge (Shattock 2017). An equally interesting direction might be to select universities based on their reputation and examine if differences between low-status and elite institutions emerge, as illustrated by Paradeise and Thoenig (2016).

Second, the goal of the empirical analysis was not to conduct in-depth analysis of the difference between Italy and England but to investigate whether the organisational dimension matters regardless of different contexts. Having recognised this limitation, the analysis still emphasises a main difference in the relationship between the organisational dimension and positioning processes in the two countries. The organisational structure positively influences positioning processes in the Italian casestudies (period 1, Univ. A, and period 2, Univ. B) when this was supervised and managed by a strong institutional leadership represented by the connection between a charismatic rector and an effective general administrative director. When these two figures are lacking, it seems that the disciplinarybased and collegial governance that characterises Italian universities is only partially able to sustain distinctive positioning efforts, as emerged from the interviews. The presence of a strong rector appears to be a necessary condition, the only element that can turn loosely coupled organisational structures into more integrated organisations. In these contexts, the coexistence of centralisation and involvement of the peripheral structures (departments) is even more important but also difficult to obtain, given that the head of departments is not appointed by the institutional leadership but is elected by the academic and administrative staff of each department. In the English system, this strong dependence on the style and capacity of the vice-chancellor does not emerge so clearly. The previous introduction of the "managerialism" and competition for funds could have contributed to 
strengthening over time hierarchical structures within universities regardless of the single vicechancellor, as underlined by Shattock (2017). Future studies on how internal members of universities perceive the influence of institutional and competitive pressures could help to investigate how the role of the organisational dimension may change in different national contexts.

\footnotetext{
Notes

${ }^{1}$ A more comprehensive illustration of the organizational dimension operationalization is provided by Fumasoli et al. (in revision).

2 NUTS3 region classification of EUROSTAT.

${ }^{3}$ Since 2014, this system has been changed and renamed as Research Excellence Framework.

${ }^{4}$ Italian rectors of public universities are elected by the academic (with tenured contracts) and administrative staff. The period of office lasts 6 years, and they cannot be re-elected as declared by the law 240 of 2010. Before 2010, the period of office lasted 4 years with the possibility of re-election.
}

\section{Funding}

We acknowledge the support by the Italian Ministry of Education, University, and Research through the PRIN 2015: 'Comparing Governance Regime Changes in Higher Education: systemic performances, national policy dynamics, and institutional responses. A multidisciplinary and mixed methods analysis (2015RJARX7).'

\section{References}

Astley, W. G., and A. H. Van de Ven. 1983. "Central Perspectives and Debates in Organization Theory”. Administrative Science Quarterly 28 (2): 245-273. doi:10.2307/2392620.

Birnbaum, R. 1991. How Colleges Work: The Cybernetics of Academic Organization and Leadership. San Francisco: Jossey-Bass.

Brown, R., and H. Carasso. 2013 Everything for Sale? The Marketisation of UK Higher Education. London and New York: Routledge and Society for Research in Higher Education.

Brunsson, N. and K. Sahlin-Andersson. 2000. "Constructing Organizations: The Example of Public Sector Reform”. Organization Studies $21 \quad$ (4): 721-746. $\quad$ doi: https://doi.org/10.1177/0170840600214003.

Byrne, D., and C. C. Ragin. 2009. The SAGE Handbook of Case-based Methods. Los Angeles: Sage.

Capano, G., M. Regini, and M. Turri. 2016. Changing Governance in Universities: Italian Higher Education in Comparative Perspective. New York: Palgrave-Macmillan.

Clark, B. R. 1983. The Higher Education System: A Cross-national Perspective. Berkeley: University of California Press. 
Czarniawska, B. 1997. Narrating the Organization: Dramas of Institutional Identity. Chicago: University of Chicago Press.

Frølich, N., and J. Caspersen. 2015. "Institutional Governance Structures." In The Palgrave International Handbook of Higher Education Policy and Governance, edited by J. Huisman, H. De Boer, D. D. Dill, and M. Souto-Otero, 379-97. New York: Palgrave Macmillan.

Fumasoli, T. 2015. "Multi-level Governance in Higher Education Research." In The Palgrave International Handbook of Higher Education Policy and Governance, edited by J. Huisman, H. De Boer, D. D. Dill, and M. Souto-Otero, 76-94. London: Palgrave Macmillan.

Fumasoli, T., and B. Lepori. 2011. "Patterns of Strategies in Swiss Higher Education." Higher Education 61 (2): 157-178. doi:https://doi.org/10.1007/s10734-010-9330-x.

Fumasoli, T., and J. Huisman. 2013. "Strategic Agency and System Diversity: Conceptualizing Institutional Positioning in Higher Education." Minerva 51 (2): 155-169. doi:https://doi.org/10.1007/s11024-013-9225-y.

Fumasoli, T., and B. Stensaker. 2013. "Organizational Studies in Higher Education: A Reflection on Historical Themes and Prospective Trends." Higher Education Policy 26 (4): 479-496. doi:https://doi.org/10.1057/hep.2013.25.

Fumasoli, T., R. Pinheiro, and B. Stensaker. 2015. Handling Uncertainty of Strategic AmbitionsThe Use of Organizational Identity as a Risk-Reducing Device, International Journal of Public Administration, 38 (13/14): 1030-1040. doi:https://doi.org/10.1080/01900692.2014.988868.

Fumasoli, T., G. Barbato, and M. Turri. (Under review). "The Determinants of University Strategic Positioning: A Reappraisal of the Organizational Dimension”.

Gioia, D. A., and H. Thomas. 1996. "Identity, Image, and Issue Interpretation: Sense-making during Strategic Change in Academia." Administrative Science Quarterly 41 (3): 370-403. doi:10.2307/2393936.

Greenwood, R., and D. Miller. 2010. "Tackling Design Anew: Getting Back to the Heart of Organizational Theory." Academy of Management Perspectives 24 (4): 78-88. https://www.jstor.org/stable/29764992.

Greenwood, R., C. R. Hinings, and D. Whetten. 2014. "Rethinking Institutions and Organizations." Journal of Management Studies 57 (7): 1206-1220. doi: https://doi.org/10.1111/joms.12070.

Greenwood, R., M. Raynard, F. Kodeih, E. R. Micelotta, and M. Lounsbury. 2011. "Institutional Complexity and Organizational Responses." The Academy of Management Annals 5 (1): 317-371. doi: https://doi.org/10.1080/19416520.2011.590299.

Kezar, A. 2004. "What is more Important to Effective Governance: Relationships, Trust, and Leadership, or Structures and Formal Processes?" New Directions for Higher Education https://doi.org/10.1002/he.154.

Maassen, P., A. Gornitzka, and T. Fumasoli. 2017. "University Reform and Institutional Autonomy: A Framework for Analysing the Living Autonomy." Higher Education Quarterly 71 (31): 239-250. doi:https://doi.org/10.1111/hequ.12129.

Morphew, C. C., T. Fumasoli, and B. Stensaker. 2018. "Changing Missions? How the Strategic Plans of Research-intensive Universities in Northern Europe and North America Balance Competing Identities." Studies in Higher Education 43 (6): 1074-1088. doi:https://doi.org/10.1080/03075079.2016.1214697. 
Paradeise, C., and J. C. Thoenig. 2013. "Academic Institutions in Search of Quality: Local Orders and Global Standards." Organization Studies $34 \quad$ (2): 189-218. doi:https://doi.org/10.1177/0170840612473550.

Paradeise C., and J. C. Thoenig. 2016. "Strategic Capacity and Organizational Capabilities: A Challenge for Universities.” Minerva 54 (3): 293-324. doi:https://doi.org/10.1007/s11024-016-9297$\underline{6}$.

Pinheiro, R., and B. Stensaker. 2014. "Designing the Entrepreneurial University: The Interpretation of a Global Idea." Public Organization Review 14 (4): 497-516. doi:https://doi.org/10.1007/s11115013-0241-z.

Pinheiro, R., and M. Young. 2017. "The University as an Adaptive Resilient Organization: A Complex Systems Perspective." In Theory and Method in Higher Education Research, Volume 3, 119-136.

Rossi, F., and V. Goglio. 2018. "Satellite University Campuses and Economic Development in Peripheral Regions." Studies in Higher Education (Article in Press). doi:https://doi.org/10.1080/03075079.2018.1506917.

Seeber, M., B. Lepori, M. Montauti, J. Enders, H. de Boer, E. Weyer, I. Bleiklie, et al. 2015. "European Universities as Complete Organizations? Understanding Identity, Hierarchy and Rationality in Public Organizations." Public Management Review 17 (10): 1444-1474. doi:https://doi.org/10.1080/14719037.2014.943268.

Seeber, M., V. Barberio, J. Huisman, and J. Mampaey. 2019. "Factors Affecting the Content of Universities' Missions Statements: An Analysis of the United Kingdom Higher Education System." Studies in Higher Education 44 (2): 230-244. doi:10.1080/03075079.2017.1349743.

Stensaker, B. 2015. "Organizational Identity as a Concept for Understanding University Dynamics." Higher Education 69 (1): 103-115. doi:https://doi.org/10.1007/s10734-014-9763-8.

Stensaker, B. and A. Vabø. 2013. "Re-inventing Shared Governance: Implications for Organisational Culture and Institutional Leadership." Higher Education Quarterly 67 (3): 356-274. doi:https://doi.org/10.1111/hequ.12019.

Stensaker B., N. Frølich, J. Huisman, L. Scordato, and P. Pimentel Bótas. 2014. "Factors Affecting Strategic Change in Higher Education." Journal of Strategy and Management 7 (2): 193-207. doi:https://doi.org/10.1108/JSMA-12-2012-0066.

Stinchcombe, A. L. 1965. Social structure and organisations, in March, J. G. (Ed.) Handbook of organisations, Rand McNally

Taylor, J., and M. D. L. Machado. 2006. "Higher Education Leadership and Management: From Conflict to Interdependence through Strategic Planning." Tertiary Education and Management 12 (2): 137-160. doi:https://doi.org/10.1007/s11233-006-0003-3.

Toma, J. D. 2010. Building Organizational Capacity: Strategic Management in Higher Education. Baltimore: Johns-Hopkins University Press.

Vuori, J. 2015. "Making Sense of Institutional Positioning in Finnish Higher Education." Tertiary Education and Management 21 (4): 316-327. doi:https://doi.org/10.1080/13583883.2015.1098722.

Vuori, J. 2016. "Towards Strategic Actorhood? The Execution of Institutional Positioning Strategies at Finnish Universities of Applied Sciences." Higher Education Quarterly 70 (4): 400-418. doi:https://doi.org/10.1111/hequ.12103. 
Weick, K. E., 1976. "Educational Organizations as Loosely Coupled Systems." Administrative Science Quarterly 21 (1): 1-19. doi: 0.2307/2391875.

Table 1. Variables, sub-dimensions, and empirical elements of the organizational dimension

\begin{tabular}{|c|l|l|}
\hline $\begin{array}{l}\text { Organizational } \\
\text { variable }\end{array}$ & Sub-dimension & Empirical elements \\
\hline \multirow{5}{*}{ (1) Structure } & (1a) centralisation vs. decentralisation & $\begin{array}{l}\text { Locus of decision-making; composition criteria, size and power of } \\
\text { the executive team; complementarity between top-management and } \\
\text { political leadership; the power of collegial bodies; allocation task; the } \\
\text { degree of faculties' autonomy in implementation; formal/informal } \\
\text { participation of academics/faculties in decision-making; }\end{array}$ \\
\cline { 2 - 3 } & (1b) formalisation vs. informality & $\begin{array}{l}\text { Presence and role of strategic planning, monitoring and evaluation } \\
\text { mechanisms; the relationship between evaluation systems and } \\
\text { decision-making. }\end{array}$ \\
\cline { 2 - 4 } & (1c) size & $\begin{array}{l}\text { Number of actors and peripherical structures involved in decision- } \\
\text { making and related coordination issues. }\end{array}$ \\
\hline \multirow{2}{*}{ (2) Identity } & (2) integration vs fragmentation & $\begin{array}{l}\text { Recognition of a historical identity; differences among disciplines; } \\
\text { membership towards the university and related management } \\
\text { processes to increase it. }\end{array}$ \\
\hline (3) Centrality & $\begin{array}{l}\text { (3a) centre vs periphery (Economic } \\
\text { terms) }\end{array}$ & $\begin{array}{l}\text { Location in industrialised areas; management of the relationships } \\
\text { with the local industry; rationale of these connections. }\end{array}$ \\
\hline (3b) centre vs periphery (Social terms) & $\begin{array}{l}\text { Number of competitors, participation in networks, collaborations, } \\
\text { official partnerships with other universities; rationale of these } \\
\text { connections. }\end{array}$ \\
\hline
\end{tabular}


Table 2 Main features of the four case-studies

\begin{tabular}{|c|c|c|c|c|c|}
\hline & & University A & University B & University $\mathbf{C}$ & University D \\
\hline \multirow{3}{*}{ GOVERNANCE } & $\begin{array}{l}\text { Number of Vice-chancellor/Rector for the } \\
\text { period 2004-2018 and selection methods }\end{array}$ & 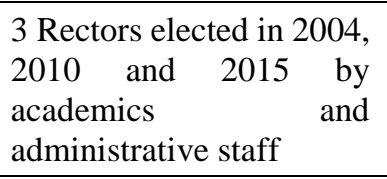 & 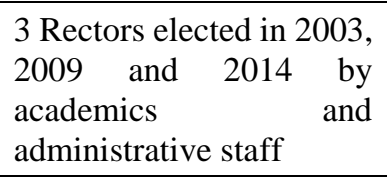 & $\begin{array}{l}1 \text { Vice-chancellor for the } \\
\text { whole period, appointed } \\
\text { by the council }\end{array}$ & $\begin{array}{l}2 \text { Vice-chancellors } \\
\text { appointed in } 2005 \text { and } \\
2015 \text {, appointed by the } \\
\text { council }\end{array}$ \\
\hline & Number of faculties/schools at $2017^{*}$ & 0 & 0 & 3 faculties & 5 schools \\
\hline & Number of departments at $2017^{* *}$ & 14 & 8 & $\begin{array}{l}12 \text { departments and } 15 \\
\text { academic areas** }\end{array}$ & $\begin{array}{l}6 \text { departments and } 17 \\
\text { academic areas }\end{array}$ \\
\hline \multirow{3}{*}{$\begin{array}{l}\text { SIZE AND } \\
\text { SUBJECT MIX }\end{array}$} & Size: number of students at 2017 & 15488 & 19603 & 14256 & 14605 \\
\hline & Size number of FTE academics at 2017 & 590 & 513 & 852 & 715 \\
\hline & Subject mix & $\begin{array}{l}\text { More generalist, with } \\
\text { medicine and engineering }\end{array}$ & $\begin{array}{l}\text { More specialized, without } \\
\text { medicine and engineering }\end{array}$ & $\begin{array}{l}\text { More specialized, with } \\
\text { medicine }\end{array}$ & $\begin{array}{l}\text { More generalist, with } \\
\text { medicine and engineering }\end{array}$ \\
\hline \multirow{4}{*}{$\begin{array}{l}\text { GEOGRAPHY AND } \\
\text { ECONOMY }\end{array}$} & Geographic position & North-East of Italy & North-East of Italy & North-west of England & Midwest of England \\
\hline & $\begin{array}{l}\text { Gross domestic product (GDP) by NUTS } 3 \\
\text { regions at 2017, in millions of euro } \\
\text { (economic centrality)*** }\end{array}$ & 9.270 & 26.594 & 43.551 & 87.843 \\
\hline & $\begin{array}{l}\text { Number of active firms by NUTS } 3 \text { regions } \\
\text { at } 2017 \text { (economic centrality) *** }\end{array}$ & 49.006 & 129.426 & 45.970 & 102.680 \\
\hline & $\begin{array}{l}\text { Number of universities within a } 50 \mathrm{~km} \\
\text { radius at } 2017 \text { (social centrality) }\end{array}$ & 1 & 2 & 10 & 8 \\
\hline
\end{tabular}

* Faculties were abolished in Italian universities with the law 240 of 2010.

** 'Academic areas' are not formal structured departments but an internal disciplinary division of a faculty

*** data about GDP are from Eurostat while data on active firms from the Office for National Statistics for England and the Istituto Nazionale di Statistica (ISTAT) for Italy. 
Table 3. Interviewees per case study and period of office of rector/vice-chancellor

\begin{tabular}{|c|c|c|c|c|}
\hline Univ. A & period 1 (2004-2009) & period $2(2010-2015)$ & period $3(2015-2018)$ & Total \\
\hline & $\begin{array}{l}\text { \#1 Rector; \#2 General director; \#3 } \\
\text { Pro-rector; \#4 Senior administrative } \\
\text { officer; \#5 Administrative officer; } \\
\text { \#6 Academics with managerial } \\
\text { responsibility; \#7 Head of } \\
\text { department }\end{array}$ & $\begin{array}{l}\text { \#8 Rector; \#9 Administrative } \\
\text { officer; \#10 Pro-rector; \#11 } \\
\text { Head of department }\end{array}$ & $\begin{array}{l}\text { \#12 Senior administrative officer; } \\
\text { \#13 Pro-rector; \#14 Academics } \\
\text { with managerial responsibility; } \\
\text { \#15 Head of department; \#16 } \\
\text { Delegate of the rector; \#17 Senior } \\
\text { Administrative officer; \#18 } \\
\text { Delegate of the rector }\end{array}$ & 18 \\
\hline Univ. B & period $1(2004-2008)$ & Period 2 (2009-2014) & period 3 (2014-2018) & \\
\hline & $\begin{array}{l}\text { \#19 Senior administrative officer; } \\
\text { \#20 Head of Department; \#21 } \\
\text { Administrative officer; \#22 } \\
\text { Academics with managerial } \\
\text { responsibilities }\end{array}$ & $\begin{array}{l}\text { \#23 Pro-rector; \#24 General } \\
\text { director; \#25 Delegate of the } \\
\text { rector; \#26, \#27, \#28 } \\
\text { Academics with managerial } \\
\text { responsibilities; }\end{array}$ & $\begin{array}{l}\text { \#29 Rector, \#30, \#31 Delegates } \\
\text { of the rector; \#32, \#33 Heads of } \\
\text { department; \#34 Senior } \\
\text { Administrative officer; \#35Vice- } \\
\text { general director }\end{array}$ & 17 \\
\hline \multirow[t]{2}{*}{ Univ. C } & \multicolumn{4}{|c|}{ (2004-2018) } \\
\hline & \multicolumn{3}{|c|}{$\begin{array}{l}\text { \#36 Vice-chancellor; \#37, \#38, \#39 Pro-vice-chancellor; \#40, \#41 Deans of Faculty; \#42 Senior } \\
\text { Administrative officer; \#43 Director of the teaching; \#44 Administrative officer; \#45, \#46 Members of the } \\
\text { faculty management-team; \#47 Registrar }\end{array}$} & 12 \\
\hline \multirow[t]{2}{*}{ Univ. D } & period $1(2005-2015)$ & \multicolumn{2}{|c|}{ period $2(2015-2018)$} & \\
\hline & $\begin{array}{l}\text { \#48 Pro-vice-chancellor, \#49 } \\
\text { Senior administrative officer; \#50, } \\
\text { \#51 Dean of Faculty }\end{array}$ & \multicolumn{2}{|c|}{$\begin{array}{l}\text { \#52 Deputy-vice-chancellor; \#53 Pro-vice-chancellor; \#54 Chief } \\
\text { Financial officer; \#55 Senior administrative officer; \#56 Associate } \\
\text { Pro-vice-chancellor; \#57, \#58 Deans of Faculty; \#59, \#60 } \\
\text { Members of the faculty management-team }\end{array}$} & 13 \\
\hline
\end{tabular}


Table 4. Propositions and intervening factors on the impact of the organizational dimension on positioning processes

\begin{tabular}{|c|c|c|c|}
\hline Variable & Dimension & Proposition & Intervening factor \\
\hline \multirow{3}{*}{ (1) Structure } & (1a) Centralisation vs. decentralisation & $\begin{array}{l}\text { Increasing centralisation leads to faster, more efficient and more } \\
\text { integrated decision-making which supports the development and } \\
\text { pursuit of institutional positioning processes }\end{array}$ & $\begin{array}{l}\text { The involvement in decision making of academics and } \\
\text { peripheral structures. }\end{array}$ \\
\hline & (1b) Formalisation vs. informality & $\begin{array}{l}\text { A formalized decision-making positively impacts on positioning since } \\
\text { it favours a more structured and objective implementation of the latter, } \\
\text { favouring the alignment between the university sub-units }\end{array}$ & $\begin{array}{l}\text { A ceremonial or superficial implementation of evaluation } \\
\text { and planning procedures and a decoupling between the } \\
\text { academic core and the managerial structure }\end{array}$ \\
\hline & (1c) Size & $\begin{array}{l}\text { A smaller size facilitates the balance between centralisation and } \\
\text { decentralisation, enhancing the involvement of the periphery and its } \\
\text { commitment towards strategic processes }\end{array}$ & $\begin{array}{l}\text { A smaller size can imply the lack of sufficient 'critical } \\
\text { mass' to obtain critical resources. OR } \\
\text { The necessity to achieve sufficient critical mass to obtain } \\
\text { appropriate resources }\end{array}$ \\
\hline (2) Identity & (2) Integration vs fragmentation & $\begin{array}{l}\text { An integrated identity has a positive impact on positioning processes } \\
\text { by generating moral incentives and enhancing collective engagement } \\
\text { for internal members towards institutional strategic efforts }\end{array}$ & $\begin{array}{l}\text { An integrated identity is the result of both enduring and } \\
\text { dynamic aspects that have to be equally managed to avoid } \\
\text { fragmentation OR } \\
\text { The capacity of the university to manage enduring and } \\
\text { dynamics aspects of organisational identity }\end{array}$ \\
\hline \multirow{2}{*}{ (3) Centrality } & (3a) Economic centrality & $\begin{array}{l}\text { Economic centrality enhances the opportunity to obtain additional and } \\
\text { diversified resources that support an effective positioning process }\end{array}$ & $\begin{array}{l}\text { A university in a peripheral location might act as an 'agent } \\
\text { of local development' OR } \\
\text { The role of the university as an "agent oflocal } \\
\text { development' in a peripheral region. }\end{array}$ \\
\hline & (3b) Social centrality & $\begin{array}{l}\text { Universities operating geographically close to several other } \\
\text { universities are forced to appear distinctive in the eyes of their } \\
\text { stakeholders in order to reduce competition and obtain critical } \\
\text { resources. }\end{array}$ & $\begin{array}{l}\text { The capacity of the university to shape cooperative } \\
\text { relationships with proximate institutions, building } \\
\text { networks and pooling resources. OR } \\
\text { The proximity to other universities could also facilitate the } \\
\text { creation of networks that help obtain symbolic and material } \\
\text { resources without competition }\end{array}$ \\
\hline
\end{tabular}

